\title{
Visitors engagement and social media in museums: evidence from Italy
}

\author{
Alberto Romolini* \\ International Telematic University Uninettuno, \\ Corso Vittorio Emanuele II, 39, 00186, Rome, Italy \\ Email: a.romolini@uninettunouniversity.net \\ *Corresponding author
}

\section{Silvia Fissi and Elena Gori}

Department of Business and Economics,

University of Florence,

Via delle Pandette, 9, 50127 Florence, Italy

Email: silvia.fissi@unifi.it

Email: elena.gori@unifi.it

\begin{abstract}
Museums are increasingly using Facebook, Twitter, YouTube and the other social media to communicate their activities and exhibitions, organise projects and debates, build and sustain communities of visitors. Moreover, one of the increasing use of social media is the engagement of actual and potential visitors. However, considering the novelty of the theme, the literature seems to be scarce and this finding suggests the necessity to study more-in-depth the use of social media in museums. Hence, the research aim is to study the use of social media for visitor engagement considering the case of Italian museums. The results show that, despite the increasing use and popularity in social media, the level of engagement in Italian museums is quite absent. Consequently, while Italian museums are very popular and well-known on social media, they are not able to use them for visitor engagement.
\end{abstract}

Keywords: visitors; engagement; social media; Facebook; Twitter; museums; Italy; frequency; popularity; virality; commitment.

Reference to this paper should be made as follows: Romolini, A., Fissi, S. and Gori, E. (2020) 'Visitors engagement and social media in museums: evidence from Italy', Int. J. Digital Culture and Electronic Tourism, Vol. 3, No. 1, pp.36-53.

Biographical notes: Alberto Romolini is currently an Associate Professor in Business Administration at the Università Telematica Internazionale Uninettuno, Rome, Italy. He is also the Vice-Dean of the Faculty of Economics in the same university. He holds a PhD in Public Management and a Master in Public Management. He currently teaches financial accounting and management control in tourism services. His research interests are in the field of corporate social responsibility (CSR) and non-financial reporting, public management in local authorities and health-care entities, museums, history of accounting and tourism management. 
Silvia Fissi is an Assistant Professor at the Department of Business and Economics of Florence University. She holds a PhD in Planning and Control from the Università degli Studi di Firenze and a Laurea (Master degree) in Economics from the same university. She currently teaches Accounting at the School of Economics and Business Administration at the School of School of Human Health Sciences. Her research interests include public management, local authorities, tourism management, museums, corporate social responsibility, and accounting history.

Elena Gori is an Associate Professor of Financial Accounting. She holds a PhD in Planning and Control from the Università degli Studi di Firenze and a Laurea (Master degree) in Economics from the same university. She currently teaches Public Management and Accounting (post graduate level) at the School of Economics. Her research interests include public management, local authorities, tourism management, museums, corporate social responsibility, and accounting history. She is the Director of the Centro Interuniversitario di Studi sul Turismo (Interuniversity Centre of Tourism Studies) of the Università degli Studi di Firenze.

\section{Introduction}

In recent years, museums have seen considerable innovation and change, considering the number of new institutions established and the different role played in the market and in society. Since the 1970s, Europe, especially, has seen pertinent growth in the number of museums (Burton and Scott, 2003). To date, thanks also to its history and culture, the EU boasts more than 19,000 museums and even more archaeological sites (EGMUS, 2018). Considering its cultural heritage, preservation is one of the EU's fundamental activities. As a result, it invested about 4.5 billion Euros in cultural heritage in the period 2007-2013 (Vassilakis et al., 2017).

As an EU member, Italy shows a similar trend. It has the greatest number of UNESCO World Heritage Sites in the world and, for this reason, Italy is a relevant case for studying innovation in museum management. Indeed, out of 1,092 sites worldwide, Italy tops the list with 54 locations. Moreover, according to the Italian National Institute of Statistics' latest data (Istat, 2017), out of the 55,000 museums in the world, 4,158 are in Italy (about 7.6\%).

According to Zafiropoulos et al. (2015), the use of ICT, the web and social media (SM) is currently transforming museum management and modifying the traditional functions of these institutions. In this way, SM enables the implementation of educational, marketing and engagement-focused practices (Langa, 2014). Museums are increasingly using Facebook (FB), Twitter (TW), YouTube and the other social tools to communicate their activities and exhibitions, organise projects and debates, build and sustain communities of visitors, reaching actual and potential supporters (Kidd, 2011).

SM is a group of internet-based applications created via the ideological and technological idea of Web 2.0. Indeed, according to Song (2010), Web 1.0 is referred to as the 'web-as-information-source', while Web 2.0 has a dichotomy perspective because it could be interpreted as the 'we-as-participation-platform'. 
SM can be described as networks of friends for social or professional interaction (Trusov et al., 2009). It is indeed a second generation of web development and its design features facilitate the sharing of information, along with users' communication and participation (Paris et al., 2010).

As a result, SM allows the creation and exchange of user generated content (Kaplan and Haenlein, 2010). SM can embody various forms - blog, microblog (TW), social network (FB) and forum (Zarrella, 2010), considering the different approaches, Trottier and Fuchs (2015) have proposed a classification based on the type of information. In this perspective, they have identified three categories: SM supporting knowledge (website), communication (e-mail) and cooperation (FB, TW, etc.). Within this study, we focus on the third category of SM.

Considering the novelty of the use of SM in museums, the literature seems to be scarce. It is necessary to study the use of SM in museums in a European and, more specifically, Italian context (Lazzeretti et al., 2015). This research analyses the concept of 'visitors' engagement'; the object being their interactive and co-creative experiences with a specific focus on online and social networking (Hollebeek et al., 2014; Imlawi and Gregg, 2014). In particular, visitors' engagement through SM can be viewed as a way to reach both actual and potential users worldwide and to disseminate information in real-time with low implementation costs.

The research aim is to study the use of SM by Italian museums to engage the visitor. First of all, the article analyses the diffusion of SM in Italian museums followed by varying approaches to engage visitors through the use of FB and TW.

The paper is organised as follows. Following the introduction, there is a discussion of the review of the literature concerning SM and users' engagement. The research method is then presented and the findings of the research regarding the Italian context are illustrated. Finally, a conclusion is drawn regarding the use of SM in Italian museums.

\section{Literature review}

Today, the application of information and communication technologies, web (Fotakis and Economides, 2008) and social media are transforming museum's activities and are modifying their traditional functions (Hung et al., 2013). SM, such as FB, TW and Instagram, can help museums to communicate their activities and exhibitions, to create digital communities and social interaction and to reach more global audiences and potential visitors (Srinivasan et al., 2009). In a context of an emerging 'digital culture' (Herdin and Egger, 2018), the role of ICT and digital technologies is crucial in attracting new visitors (Bakhshi and Throsby, 2012; Parry, 2007), providing interactivity, immersive experience and creative engagement (Cerquetti, 2016). In this perspective, museums facilitate visitors' accessibility to digital culture contents and have a fundamental role in spreading it (Drigas et al., 2009).

Moreover, SM is increasingly important as a tool for gathering information about services and for taking advantage of new opportunities (Verhoef and Lemon, 2013; Högberg, 2017). In this perspective, SM can be interpreted as an innovative way for visitor engagement, providing interactivity and an immersive experience in a visitor-oriented approach (Bertacchini and Morando, 2013; Cerquetti, 2016). Moreover, SM can help cultural institutions to be more competitive and sustainable, increasing the value creation for stakeholders. In this context, Camarero and Garrido (2008) find a 
correlation between technological innovation and economic performance, in that the use of digital technologies could help museums to better achieve a more valuable economic performance. In the same sense, Nuccio and Bertacchini (2016) underline the opportunity for museums to more deeply understand consumer perceptions and feelings through the use of digital technologies. This information can allow cultural institutions to re-orient the value provided for visitors and the organisational and managerial practices, in a digital sense.

According to Burnett (2000), the participation of a visitor in a digital community can be passive or active. Passive visitors only browse the institutional website and use SM to discover useful information for the onsite experience, without contributing or sharing feelings with other community participants. The progressive use of SM is changing visitors' role from passive to proactive through user-generated content: visitors are turning, especially in SM, towards active participation with the online community (Fletcher and Lee, 2012). Active members are highly interested in participating in SM, realising different forms of activities, such as creating content and messages and disseminating information. Fundamentally, converting passive members to active participants is critical in creating vital online communities and is a vital constituent for the success of the digital environment (Kang et al., 2014). In this way, visitors are currently 'prosumers' (Garibaldi, 2015; Toffler, 1980) who can produce independent content and new ideas, express their experience, share memories and observations, upload photographs and videos taken during the visit (de Bernardi et al., 2018). In other words, the use of SM is transforming visitors from passive observers to active content creators and museum ambassadors (Kidd, 2011).

In recent years, organisations have been using SM to also build and strengthen their relationships with stakeholders in order to transform this process into 'real' stakeholder engagement (SE). Thanks to SE, museums can interact with stakeholders via 'two-way communication' (Manetti, 2011; Owen et al., 2001), building forms of collaboration and realising a process of knowledge co-creation (Freeman and Evan, 1990). These positive externalities can also support the management in the strategic decision process (Ayuso et al., 2006).

Visitor engagement is a strategy for a museum to increase the interaction of its visitors with the institution (Chang et al., 2014). Museums need to invest in SM to foster relationships and interact with customers urging people to talking about the organisation (de Vries et al., 2012). Scholars identified three different dimensions to measure visitors' engagement in SM: popularity, commitment and virality (Camarero et al., 2018; Su et al., 2015). Popularity can be measured through the number of 'likes' in SM such as FB and TW and it is linked to museum awareness. The dimensions of commitment are the active involvement of visitors interacting within the social network. Commitment can be measured by the number of comments provided by the visitors to a museum's fan page. Thanks to the commitment, members of the social community are not only visitors but also producers of digital content. The virality, finally, is the visitor engagement through active involvement in disseminating knowledge. The number of reports and shares in SM, according to Hoffman and Fodor (2010), is a measure of virality.

In the light of the literature review, the aim of this research is to measure the use of SM for user-engagement in the museum industry through the dimensions of popularity, commitment and virality. The study is positioned in the Italian context considering the 
relevance of the country's heritage assets and the importance of cultural industry in European countries. The research question is the following:

- What is the level of popularity, commitment and virality in museums' user-engagement?

\section{Research design}

The research is exploratory in nature and focuses on Italian State public museums. In particular, it considers the museums included in the 'Top 30 Italian museums', an annual ranking of Italian public and private museums calculated on the basis of visitor numbers.

After the identification of the target of the research, the study uses an approach similar to the method proposed by Brainard and Edlins (2015) and Bellucci and Manetti (2017), applied namely for the American police departments and for US philanthropic foundations.

First, the research identifies the SM utilised by each museum. After that, the research concentrates on the SM for each museum classified as 'community relationships' - namely, FB and TW - leaving out the channels 'community interests', such as YouTube, Instagram and Pinterest (Ang, 2011). More specifically, FB and TW have been identified as the most consistent SM with regards to the research aim, given that they are most used globally (Statista, 2018) and by artistic-cultural organisations [Thomson et al., (2013), pp.25-26].

Therefore, for each official FB and TW profile, a descriptive analysis has been managed for the period 10 January 2017-31 December 2017 (12 weeks). The analysis considers the dimensions of visitors' engagement through a quantitative study. The data is analysed, derived from the official fan page on FB and TW and consists of a number of 'likes', posts/tweets, comments and shares.

\section{Results and discussion - an overview}

The first step of this research was the identification of SM used by Italian State museums. The research has encountered some difficulties because museums' official websites sometimes do not contain a direct link to social platforms. Therefore, in some cases, it was necessary to access these platforms in order to verify whether or not there were official social profiles. This means that some institutions are not fully taking advantage of the opportunity offered by their websites in facilitating interaction and relationship-building between museums and their public (Capriotti et al., 2016). In this light, museum professionals should pay more attention to the information provided within their institutional websites (Marty, 2008). Indeed, some authors (i.e., Heinze and $\mathrm{Hu}$, 2006; Park and Reber, 2008; Guillory and Sundar, 2014) show that organisations are still the first step of migration from an unidirectional website to a dialogic version.

Of the 30 studied institutions, 28 museums have at least one active SM profile (Table 1). Consequently, these institutions are far more active on SM than the rest of Italy's museums, which are present on at least one platform in $40.5 \%$ of cases (Istat, 2017). This result is in contrast to previous studies, which showed Italian museums' limited presence on SM (Sibilio Parri and Manetti, 2014), while this study seems to suggest a rapid growth in their use. 
Visitors engagement and social media in museums

Table 1 Museums and SM

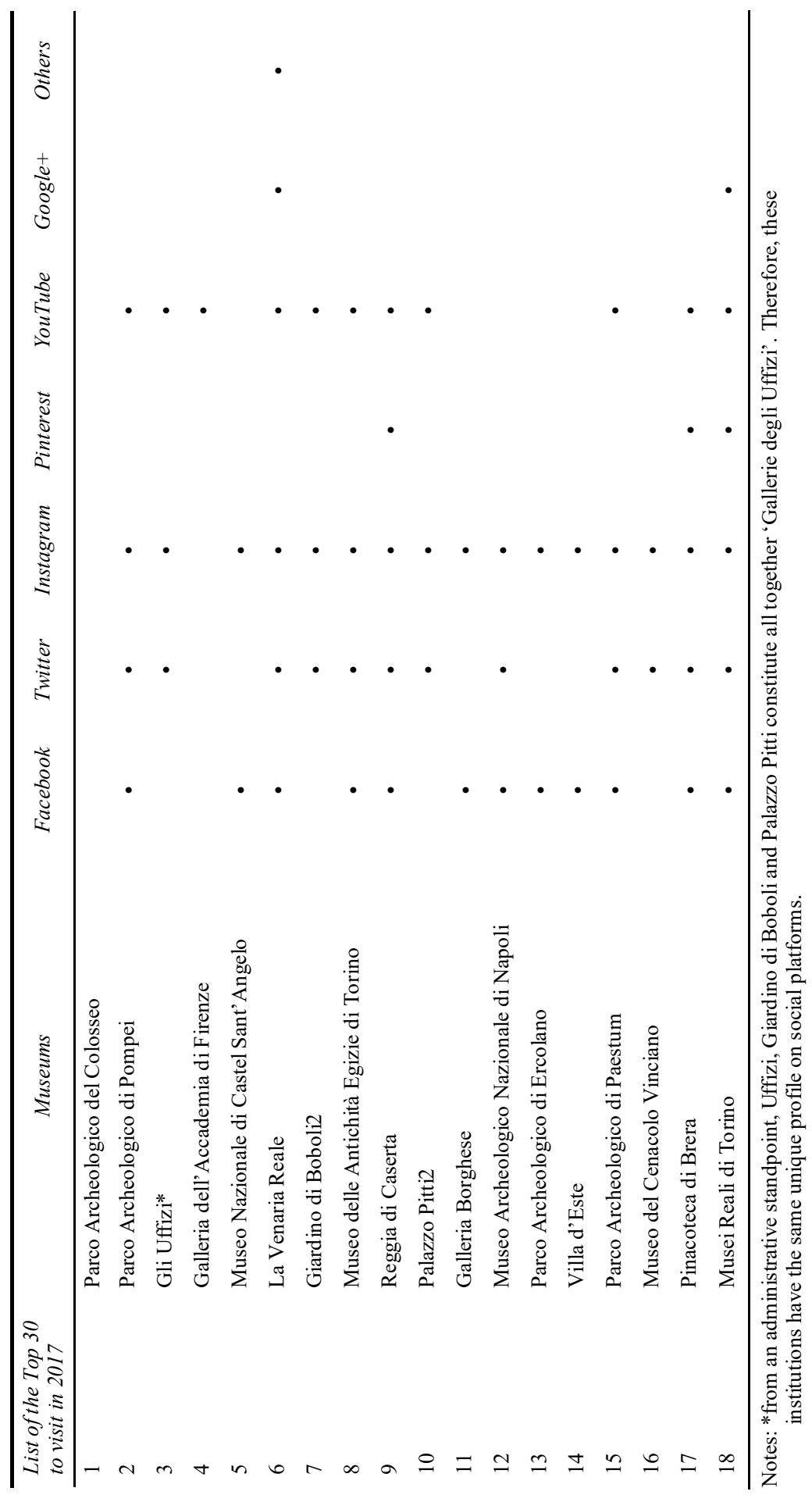


Table 1 Museums and SM (continued)

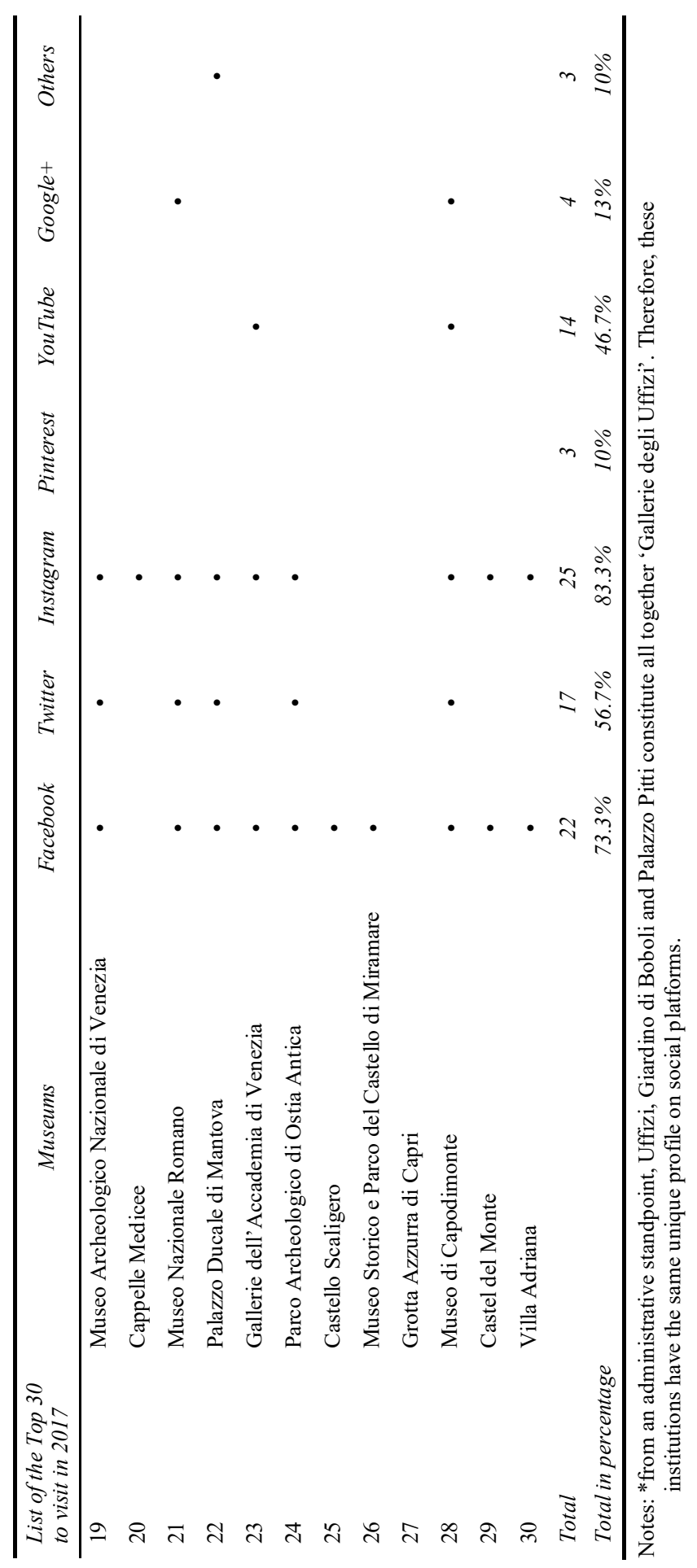


Surprisingly, it is interesting to note that the most visited museum, Parco Archeologico del Colosseo, does not have an official social account, and that Galleria dell'Accademia di Firenze, although occupying fourth place in the ranking of the most visited Italian museums, is active on only one (YouTube). These relevant institutions do not exploit the dialogic potential of SM (Capriotti and Kuklinski, 2012).

Nowadays, museums usually use a mix of SM because social platforms differ significantly from one another, having their own set of advantages and drawbacks (Kaplan and Haenlein, 2010; Kietzmann et al., 2011). Also, for this reason, museums should develop a social media strategy according to their specific mission and goals (Suzić et al., 2016a), thereby using SM in a strategic way.

Considering the museums being studied, the two most used 'community relationships' tools are FB (73.3\%) and TW (56.7\%) while, among the 'community interests' SM, there are Instagram (83.3\%) and YouTube (46.7\%) (Table 1). The study reveals that museums are active, on average, on three SM sites, using two 'community relationships' tools jointly (FB and TW) and one means of communicating the 'communities' interests' (usually Instagram). The mix choice is mainly consistent with users' preferences, considering that FB, Instagram and TW are among the most used SM (first, third and fifth respectively) by Italian users (Statista, 2018). In addition, the study also points out that Italian museums show a more contained use of YouTube and, even more, Google+, which are among the most employed sites (second and fourth, respectively) by Italian users (Statista, 2018).

From now on, the analysis will focus only on FB and TW because these platforms enable not only the sharing of photos and videos, but also messages and posts, appearing to be the most suitable tools for studying visitors' engagement in the cultural sector (Camarero et al., 2018; Langa, 2014).

From an historical point of view, the 28 museums have started joining FB and TW in 2009 (Figure 1), which is respectively 5 and 3 years after these platforms were created. Non-profit entities (such as museums) have shown a substantial delay in SM adoption compared to profit-driven organisations (Waters et al., 2009); notwithstanding, this study finds a rapid growth in the adoption of these social platforms, especially in the case of FB, which was adopted before TW.

Figure 1 FB and TW adoption by Italian State museums

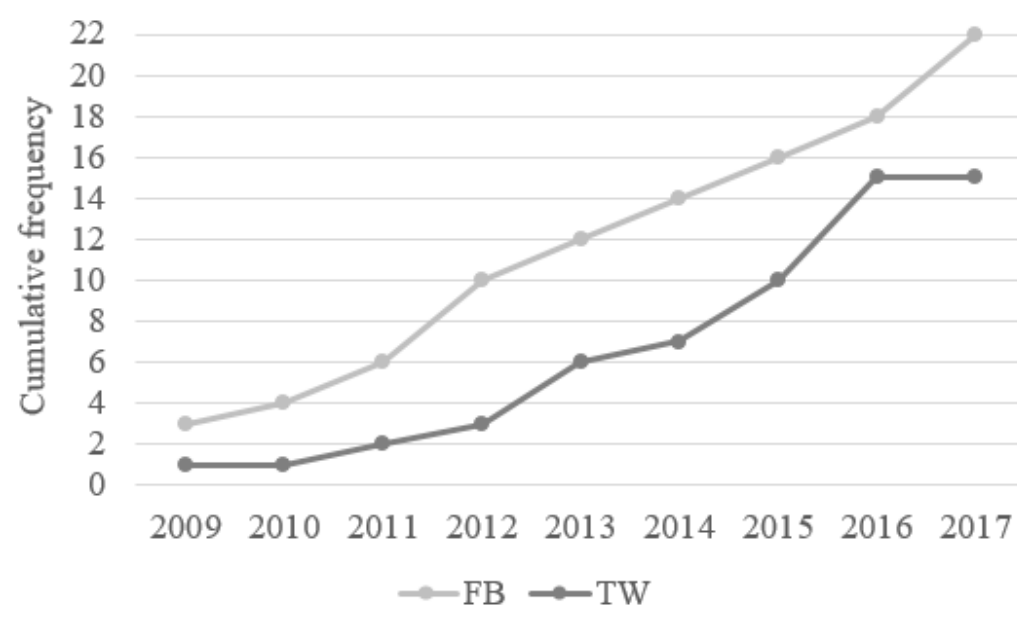


Furthermore, the analysis reveals that the pioneer institutions are La Venaria Reale (which launched both its FB and TW pages in 2009), followed by Museo delle Antichità Egizie di Torino and Museo di Capodimonte.

\section{Visitors engagement and social media}

Referring to our research question, the research also analyses visitors' engagement through the study of popularity, commitment and virality, to more deeply understand museums' capacity to engage visitors.

\subsection{The popularity dimension}

The number of 'likes' represents the popularity of the SM audience (Suzić et al., 2016b). In this sense, SM may help museums to develop and improve long-lasting relationships with the virtual community, so fulfilling their social role (Simon, 2007; Wright and Hinson, 2008).

Table 2 Museums' popularity

\begin{tabular}{|c|c|c|c|c|c|}
\hline \multirow[t]{2}{*}{ Museums } & \multirow{2}{*}{$\begin{array}{c}\text { Annual } \\
\text { visitors in } \\
2017\end{array}$} & \multicolumn{2}{|c|}{$\begin{array}{l}\text { Total posts/ } \\
\text { tweets }\end{array}$} & \multicolumn{2}{|c|}{ Likes } \\
\hline & & $F B$ & $T W$ & $F B$ & $T W$ \\
\hline Parco Archeologico del Colosseo & $7,036,104$ & & & & \\
\hline Gli Uffizi & $3,825,086$ & & 257 & & 29,387 \\
\hline Parco Archeologico di Pompei & $3,383,415$ & 105 & 87 & 101,361 & 20,680 \\
\hline Galleria dell'Accademia di Firenze & $1,623,690$ & & & & \\
\hline Museo Nazionale di Castel Sant'Angelo & $1,155,244$ & 65 & & 6,290 & \\
\hline La Venaria Reale & $1,048,857$ & 131 & 60 & 266,583 & 22,907 \\
\hline Museo delle Antichità Egizie di Torino & 850,465 & 96 & 44 & 183,154 & 26,582 \\
\hline Reggia di Caserta & 838,654 & 101 & 97 & 188,229 & 9,142 \\
\hline Galleria Borghese & 568,982 & 11 & & 5,501 & \\
\hline $\begin{array}{l}\text { Museo Archeologico Nazionale di } \\
\text { Napoli }\end{array}$ & 529,583 & 134 & 6 & 33,135 & 6,576 \\
\hline Parco Archeologico di Ercolano & 470,123 & 53 & & 10,323 & \\
\hline Villa d'Este & 461,037 & 54 & & 10,676 & \\
\hline Parco Archeologico di Paestum & 441,196 & 98 & 38 & 61,768 & 3,484 \\
\hline Museo del Cenacolo Vinciano & 416,347 & & 8 & & 653 \\
\hline Pinacoteca di Brera & 364,541 & 90 & 38 & 33,679 & 93,520 \\
\hline Musei Reali di Torino & 360,847 & 78 & 59 & 33,297 & 10,865 \\
\hline $\begin{array}{l}\text { Museo Archeologico Nazionale di } \\
\text { Venezia }\end{array}$ & 343,582 & 12 & 2 & 4,765 & 10,380 \\
\hline Cappelle Medicee (Musei del Bargello) & 339,870 & & & & \\
\hline Museo Nazionale Romano & 328,579 & 100 & 3 & 42,699 & 996 \\
\hline Palazzo Ducale di Mantova & 323,255 & 30 & 27 & 6,096 & 812 \\
\hline
\end{tabular}


Table 2 Museums' popularity (continued)

\begin{tabular}{|c|c|c|c|c|c|}
\hline \multirow{2}{*}{ Museums } & \multirow{2}{*}{$\begin{array}{c}\text { Annual } \\
\text { visitors in } \\
2017\end{array}$} & \multicolumn{2}{|c|}{$\begin{array}{l}\text { Total posts/ } \\
\text { tweets }\end{array}$} & \multicolumn{2}{|c|}{ Likes } \\
\hline & & $F B$ & $T W$ & $F B$ & $T W$ \\
\hline Gallerie dell'Accademia di Venezia & 316,995 & 50 & & 19,559 & \\
\hline Parco Archeologico di Ostia Antica & 311,384 & 34 & 11 & 6,225 & 939 \\
\hline Castello Scaligero & 298,615 & 13 & & 2,047 & \\
\hline $\begin{array}{l}\text { Museo Storico e Parco del Castello di } \\
\text { Miramare }\end{array}$ & 293,911 & 82 & & 2,492 & \\
\hline Grotta Azzurra di Capri & 263,741 & & & & \\
\hline Museo di Capodimonte & 262,440 & 119 & 144 & 58.781 & 6,173 \\
\hline Castel del Monte & 249,527 & 14 & & 5,995 & \\
\hline Villa Adriana & 242,772 & 33 & & 12,364 & \\
\hline Mean & & 68.3 & 58.7 & $49,344.7$ & $16,206.4$ \\
\hline Standard deviation & & 39.2 & 65.8 & $72,089.0$ & $22,707.8$ \\
\hline
\end{tabular}

Table 3 Publication frequency

\begin{tabular}{lcc}
\hline \multirow{2}{*}{ Publication frequency } & M & Museums \\
\cline { 2 - 3 } & 1 & $5 W$ \\
\hline Fewer than 1 post/tweet per week (quasi inactive) & 6 & 5 \\
Between 1 and 4 posts/tweets per week (very low) & 6 & 2 \\
Between 4 and 7 posts/tweets per week (low) & 13 & 11 \\
Number of museums under the line & 7 & 2 \\
Between 7 and 10 posts/tweets per week (adequate) & 2 & 1 \\
Between 10 and 15 posts/tweets per week (high) & 0 & 1 \\
More than 15 posts/tweets per week (very high) & 9 & 4 \\
Number of museums over the line & $\mathbf{2 2}$ & $\mathbf{1 5}$ \\
Total & & \\
\hline
\end{tabular}

First of all, the study shows that, in general, FB profiles are more followed than those on TW; indeed, the average number of 'likes' on the FB page is equal to 49,345 while the number of those on the TW page accounts for barely 16,206 (Table 2). However, it should be noted that there is a great range and dispersion of the values (i.e., standard deviation is greater than the means). This reveals a high differentiation among the museums' accounts, meaning that some museums (actually very few) are strongly followed on SM (in particular, La Venaria Reale on FB and Pinacoteca di Brera on TW), while others have a lower number of followers.

Regarding total posts or tweets published online, the analysis points out that these institutions use, in general, FB more than TW, with an average number of posts and tweets of 68.3 and 58.7, respectively. This is consistent with the fact that FB is, in general, more employed than TW by Italian users (Statista, 2018).

The 'posting activity' refers to the level of museums' activity on SM, in terms of both publication frequency and total posts or tweets made on social platforms in the last quarter of 2017. In order to analyse the publication frequency, the study follows a similar 
approach to that adopted by Capriotti and Losada Diaz (2018). The results reveal that most museums (13 on FB and 11 on TW) have, in general, an inadequate frequency of publication (Table 3); among these institutions, there are six museums (one on FB and five on TW) which can even be considered as quasi-inactive on social platforms, as they post fewer than one post/tweet per week. Furthermore, the study shows that even museums that are in an 'over the line' position (i.e., publishing more than seven posts per week) have, at most, an 'adequate' frequency of publication; only one museum (Gallerie degli Uffizi) publishes more than 15 tweets per week. This means that, despite the increasing awareness of the important role played by SM in relationship building, museums show a low level of activity on SM in terms of publication frequency, consistent with the findings of previous studies (Capriotti and Losada-Díaz, 2018; Suzić et al., 2016a).

Moreover, in order to more thoroughly explore the museums being studied, these institutions have been grouped according to the character of their contents, as follows:

- Museums and galleries, which comprise art institutions, that is the "depository for the aesthetic products of man's creative genius, such as paintings, sculptures, architecture" [Goode, (1896), p.154], and archaeological museums, mainly characterised by the fact that their collections come all or partly from excavations (EGMUS, 2018).

- Archaeological parks, which are "land area characterised by important archaeological evidence and the presence of historical, landscape or environmental values, and the presence of a specific open-air museum" (Italian Code of Cultural Heritage and Landscape).

- Royal palaces, villas and castles, which comprise - on one hand - grand residences of royals or high-ranking dignitary and - on the other - fortified structures built during the middle ages.

In the light of this classification, the study reveals that the most active institutions on SM are 'museums and galleries' (on average, 59.7\% of total posts and tweets), followed by 'royal palaces, villas and castles' (22.9\%), and 'archaeological parks' (17.4\%) (Figure 2).

Figure 2 The most active institutions

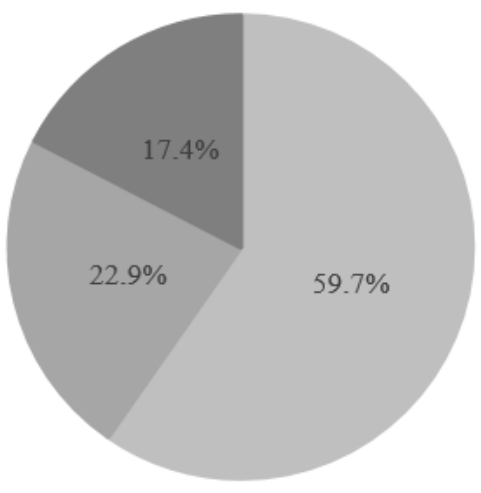


Considering the previous study by Camarero et al. (2018), the frequency results for Italian museums are higher than those in an international context. It is important to note that Camarero considers a different and larger sample of museums from Europe, North and Latin America and other countries. Nevertheless, the number of likes for the Italian museum has an average of 49,345 for FB and 16,206 for TW, versus 1,245.27 for FB in Camarero's study. The results show that the popularity of Italian museums in SM is very high compared to the approach used in other countries. Finally, we observe that the deviation standard is also lower in the Italian analysis, highlighting a more homogeneous use of SM.

\subsection{The commitment and virality dimensions}

Another measure for visitor engagement through the use of SM is the 'commitment'. This topic can be analysed with the evaluation of the average number of comments per post/tweet on FB and TW. Moreover, the analysis has been strengthened with the consideration of the museums' reaction to visitors' comments. This element is studied through the analysis of the museums' answers to comments on FB and TW (Table 4). Indeed, the ability to like and share represents important forms of 'participation expressions' by the public (Smørdal et al., 2014).

The analysis shows that both the 'average number of comments for post/tweet' (5.1 on FB and 0.6 on TW), indicating the 'size' of the virtual dialogue, and the 'percentage of museums' answer to comments ( $4.5 \%$ on FB and $3.4 \%$ on $\mathrm{TW})$, measuring the feedback of institutions, are quite low, especially within TW. Indeed, considering the work of Camarero et al. (2018), the average number of the international context is 28.72 , with a higher level of commitment compared to Italian museums. These results show that museums have scant interest in promoting the conversation that they themselves generated within their official profiles; in some cases, the interaction between museums and users is absent, even. It is consistent with previous studies regarding the use of SM as unidirectional tools, with a limited level of interaction (Capriotti and Losada-Díaz, 2018).

Table 4 Commitment and virality analysis of visitors' engagement

\begin{tabular}{|c|c|c|c|c|c|c|c|c|}
\hline \multirow{3}{*}{ Museums } & \multicolumn{4}{|c|}{ Commitment } & \multicolumn{4}{|c|}{ Virality } \\
\hline & \multicolumn{2}{|c|}{$\begin{array}{l}\text { Average } \\
\text { number of } \\
\text { comments } \\
\text { per post/ } \\
\text { tweet }\end{array}$} & \multicolumn{2}{|c|}{$\begin{array}{l}\text { Percentage of } \\
\text { museums, } \\
\text { answer to } \\
\text { comments }\end{array}$} & \multicolumn{2}{|c|}{$\begin{array}{l}\text { Average } \\
\text { number of } \\
\text { shares per } \\
\text { post/tweet }\end{array}$} & \multicolumn{2}{|c|}{$\begin{array}{l}\text { Average } \\
\text { number of } \\
\text { likes per } \\
\text { post/tweet }\end{array}$} \\
\hline & $F B$ & $T W$ & $F B$ & $T W$ & $F B$ & $T W$ & $F B$ & $T W$ \\
\hline Museums and galleries & 1.7 & 0.7 & $8.1 \%$ & $6.2 \%$ & 9.5 & 22.5 & 50.5 & 50.2 \\
\hline Archaeological parks & 8.8 & 0.8 & $4.7 \%$ & $2.2 \%$ & 75.2 & 28.1 & 373.4 & 66.6 \\
\hline $\begin{array}{l}\text { Royal palaces, villas } \\
\text { and castles }\end{array}$ & 4.8 & 0.4 & $0.9 \%$ & $1.6 \%$ & 30.4 & 6.3 & 201.4 & 19.3 \\
\hline Mean & 5.1 & 0.6 & $4.5 \%$ & $3.4 \%$ & 38.4 & 19.0 & 208.4 & 45.4 \\
\hline Standard deviation & 2.9 & 0.2 & $2.9 \%$ & 2.1 & 27.4 & 9.3 & 132.0 & 19.6 \\
\hline
\end{tabular}


The 'virality' on SM is the third dimension of visitors' engagement and it can be analysed referring to the average number of shares and likes per post/tweet (Table 4). The 'virality' in visitors' engagement is larger with FB posts (208.4 likes and 38.4 shares per post) than with tweets (45.4 likes and 19 shares per post) (Table 4). However, the results show a lower virality for Italian museums compared to what happens in the international context. Camarero et al. (2018) demonstrate an average number of shares (345.74), higher than the same result in the Italian museums.

In line with other studies (Suzić et al., 2016a), the analysis confirms that the followers of museums predominantly use the 'like' function, while the 'share' is rarely used. However, it is necessary to note that there is a wide range and dispersion of the values (see the value of SDs), suggesting that the level of appreciation towards museums' activities varies significantly.

From another perspective, it is interesting to more deeply analyse the effective level of interaction between museums and users. Indeed, SM - on one hand - allows users to express their experiences and share their observations, photos and videos (Zafiropoulos et al., 2015), transforming visitors from passive observers to active participators (Holdgaard and Klastrup, 2014), and - on the other hand - enable museums to move towards a more dialogic approach to their users/visitors (Smørdal et al., 2014).

\section{Conclusions}

The paper analyses the use of SM in Italian museums with particular attention to visitors' engagement. The research has firstly drawn a picture of SM adoption in Italian museums. Concerning the institutions studied, representing the most visited museums in Italy, we observe that 28 of 30 museums are active on SM and they use a mix of platforms with a prevalence of FB and TW. The results show that Italian museums nowadays are very involved in the use of SM with a rapid growth in their adoption, especially over the last ten years.

Concerning the research question, this study intends to evaluate the level of popularity, commitment and virality in the museum user engagement.

The popularity of museums in SM could be analysed through the number of likes. Considering previous studies, our results show that the popularity of Italian museums in $\mathrm{SM}$ is higher compared to the same topic at the international level. Indeed, the number of 'likes' for the Italian museum has an average of 49,345 for FB and 16,206 for TW, versus 1,245.27 for FB founded in other countries (Camarero et al., 2018). Therefore, the results suggest that Italian museums' rapid expansion in the use of SM has the consequence of raising the popularity of these institutions. However, the results also show that, considering the frequency of publication, Italian museums still have a low activity level in this field. Thus, they need to increase the frequency of publication in FB and TW to strengthen their relationships with visitors and to continue to increase their popularity.

Another way to measure visitor engagement in SM is commitment. This topic is analysed considering the average number of comments per post and tweet. Surprisingly, the study shows that the commitment in Italian museums is lower than has been observed in the international context. This result also suggests that the level of engagement 
between museums and visitors is quite absent in Italian institutions. In other words, if Italian museums are very popular on FB and TW, they use SM only in one-way communication without developing an engagement approach. In this perspective, museums need to work harder to reach the opportunities offered by these platforms to engage visitors and to consider SM as a powerful channel, not only as a tool to communicate the 'brand' of institution in a unidirectional way.

A different measure for visitor engagement in SM is the virality: this could be evaluated through the average number of shares and likes per post/tweet. Our results show a lower level of virality in SM for Italian museums compared with the same performance in other countries. The finding is in line with the previous studies and it indicates that Italian museums are popular on SM where they are very present and well known. However, at the same time, they are not able to use SM for visitor engagement. Currently, Italian museums are considering SM only as a tool to increase the visibility of their institutions without taking advantage of the opportunity to engage customers and build a loyalty relationship with stakeholders.

This research suggests to managers the importance of the SM use in different perspectives. The first one is the possibility to reach a high level of popularity for the museum brand. This is an important issue especially for museums located in small towns far from the Italian traditional destination. Moreover, SM could be used to engage the potential visitors in an international context. The research shows that this element needs to be strengthened by managers in the future. Finally, for the Italian museums, SM could be a powerful tool to increase the number of visitors and to create a digital community by engaging people before and after the visit experience.

The research has some limitations: however, these can be considered as future developments. Firstly, the research's results have been influenced by the sample used, starting with the choice to investigate Italian museums. The results could be useful in comparison with another sample coming from European and non-European states to analyse different approaches for visitors' engagement through the use of SM.

Usually, the researches on this topic are concentrated on the biggest and most visited institutions. It could be an interesting approach to extend the study to the smallest institutions to analyse the use of SM in museums characterised by a lower level of financial and human resources.

In line with previous research on the same topic, the analysis period is rather limited (the last quarter of 2017). Therefore, it is possible that, considering a different observation time, the results could change. In this regard, indeed, it should be noted that the results could change radically, even after a short period of time, in consideration of the quick modification in SM.

\section{References}

Ang, L. (2011) 'Community relationship management and social media', Journal of Database Marketing \& Customer Strategy Management, Vol. 18, No. 1, pp.31-38.

Ayuso, S., Rodriguez, M.A. and Ricart, J.A. (2006) 'Using stakeholder dialogue as a source for new ideas: a dynamic capability underlying sustainable innovation', Corporate Governance, Vol. 6, No. 4, pp.475-490.

Bakhshi, H. and Throsby, D. (2012) 'New technologies in cultural institution: theory, evidence and policy implications', International Journal Cultural Policy, Vol. 18, No. 2, pp.205-222. 
Bellucci, M. and Manetti, G. (2017) 'Facebook as a tool for supporting dialogic accounting? Evidence from large philanthropic foundations in the United States', Accounting, Auditing \& Accountability Journal, Vol. 30, No. 4, pp.874-905.

Bertacchini, E. and Morando, F. (2013) 'The future of museums in the digital age: new models of access and use of digital collections', International Journal of Arts Management, Vol. 15, No. 2, pp.60-72.

Brainard, L. and Edlins, M. (2015) 'Top 10 U.S. municipal police departments and their social media usage', The American Review of Public Administration, Vol. 45, No. 6, pp.728-745.

Burnett, G. (2000) 'Information exchange in virtual communities: a typology', Information Research, Vol. 5, No. 4, pp.60-83.

Burton, C. and Scott, C. (2003) 'Museums: challenges for the 21st century', International Journal of Arts Management, Vol. 5, No. 2, pp.56-68.

Camarero, C. and Garrido, M.J. (2008) 'The role of technological and organizational innovation in the relation between market orientation and performance in cultural organizations', European Journal of Innovation Management, Vol. 11, No. 3, pp.413-434.

Camarero, C., Garrido, M.J. and San Jose, R. (2018) 'What works in Facebook content versus relational communication: a study of their effectiveness in the context of museums', International Journal of Human-Computer Interaction, Vol. 34, No. 12, pp.1119-1134.

Capriotti, P. and Kuklinski, H.P. (2012) 'Assessing dialogic communication through the internet in Spanish museums', Public Relations Review, Vol. 38, No. 4, pp.619-626.

Capriotti, P. and Losada-Díaz, J. (2018) 'Facebook as a dialogic communication tool at the most visited museums of the world', El Profesional de la Información, Vol. 27, No. 3, pp.642-650.

Capriotti, P., Carretón, C. and Castillo, A. (2016) 'Testing the level of interactivity of institutional websites: from Museums 1.0 To Museums 2.0', International Journal of Information Management, Vol. 36, No. 1, pp.97-104.

Cerquetti, M. (2016) 'More is better! Current issues and challenges for museum audience development: a literature review', Journal of Cultural Management and Policy, Vol. 6, No. 1, pp.30-43.

Chang, T.L., Marcketti, S. and Fiore, A.M. (2014) 'Use of social networking services for marketing art museums', Museum Management and Curatorship, Vol. 29, No. 2, pp.1-18.

de Bernardi, P., Gilli, M. and Colomba, C. (2018) 'Unlocking museum digital innovation. Are 4.0 Torino museums?', in Cantino V., Culasso, F. and Racca, G. (Eds.): Smart Tourism, pp.453-471, McGraw-Hill Education, Milan.

de Vries, L., Gensler, S. and Leeflang, P.S.H. (2012) 'Popularity of brand posts on brand fan pages: an investigation of the effects of social media marketing', Journal of Interactive Marketing, Vol. 26, No. 2, pp.83-91.

Drigas, A., Koukianakis, L. and Glentzes, J. (2009) 'An e-culture - e-museums environment for common citizens and disabled individuals', International Journal of Digital Culture and Electronic Tourism, Vol. 1, No. 4, pp.267-279.

EGMUS (2018) European Group on Museums Statistics [online] http://www.egmus.eu (accessed 4 February 2019).

Fletcher, A. and Lee, M. (2012) 'Current social media uses and evaluation in American museums', Museum Management and Curatorship, Vol. 27, No. 5, pp.505-521.

Fotakis, T. and Economides, A.A. (2008) 'Art, science/technology and history museums on the web', International Journal of Digital Culture and Electronic Tourism, Vol. 1, No. 1, pp.37-63.

Freeman, R.E. and Evan, W. (1990) 'Corporate governance: a stakeholder interpretation', Journal of Behavioural Economics, Vol. 19, No. 4, pp.337-359.

Garibaldi, R. (2015) 'The use of Web 2.0 tools by Italian contemporary art museums', Museum Management and Curatorship, Vol. 30, No. 3, pp.230-243. 
Goode, G.B. (1896) 'On the classification of museums', Science, Vol. 3, No. 57, pp.154-161.

Guillory, J.E. and Sundar, S.S. (2014) 'How does web site interactivity affect our perceptions of an organization?', Journal of Public Relations Research, Vol. 26, No. 1, pp.44-61.

Heinze, N. and Hu, Q. (2006) 'The evolution of corporate web presence: a longitudinal study of large American companies', International Journal of Information Management, Vol. 26, No. 4, pp.313-325.

Herdin, T. and Egger, R. (2018) 'Beyond the digital divide: tourism, ICTs and culture - a highly promising alliance', International Journal of Digital Culture and Electronic Tourism, Vol. 2, No. 4, pp.322-336.

Hoffman, D.L. and Fodor, M. (2010) 'Can you measure the ROI of your social media marketing?', MIT Sloan Management Review, Vol. 52, No. 1, pp.40-49.

Högberg, K. (2017) 'Social media adoption: an exploratory international case study of hotel organizations', International Journal of Digital Culture and Electronic Tourism, Vol. 2, No. 1, pp.67-82.

Holdgaard, N. and Klastrup, L. (2014) 'Between control and creativity: challenging co-creation and social media use in a museum context', Digital Creativity, Vol. 25, No. 3, pp.190-202.

Hollebeek, L.D., Glynn, M.S. and Brodie, R.J. (2014) 'Consumer brand engagement in social media: conceptualization, scale development and validation', Journal of Interactive Marketing, Vol. 28, No. 2, pp.149-165.

Hung, S.Y., Chen, C.C., Hung, H.M. and Ho, W.W. (2013) 'Critical factors predicting the acceptance of digital museums: user and system perspectives', Journal of Electronic Commerce Research, Vol. 14, No. 3, pp.231-243.

Imlawi, J. and Gregg, D. (2014) 'Engagement in online social networks: the impact of self-disclosure and humor', International Journal of Human-Computer Interaction, Vol. 30, No. 2, pp.106-125.

Istat (2017) Report Musei, Museums' report [online] http://www.istat.it (accessed 18 December 2018).

Kang, J., Tang, L. and Fiore, A.M. (2014) 'Enhancing consumer-brand relationships on restaurant Facebook fan pages: maximizing consumer benefits and increasing active participation', International Journal of Hospitality Management, Vol. 36, pp.145-155.

Kaplan, A.M. and Haenlein, M. (2010) 'Users of the world, unite! The challenges and opportunities of social media', Business Horizons, Vol. 53, No. 1, pp.59-68.

Kidd, J. (2011) 'Enacting engagement online: framing social media use for the museums', Information, Technology and People, Vol. 24, No. 1, pp.64-77.

Kietzmann, J.H., Hermkens, K., McCarthy, I.P. and Silvestre, B.S. (2011) 'Social media? Get serious! Understanding the functional building blocks of social media', Business Horizons, Vol. 54, No. 3, pp.241-251.

Langa, L. (2014) 'Does Twitter help museums engage with visitors?', iConference 2014 Proceedings, pp.484-495.

Lazzeretti, L., Sartori, A. and Innocenti, N. (2015) 'Museums and social media: the case of the Museum of Natural History of Florence', International Review on Public and Nonprofit Marketing, Vol. 12, No. 3, pp.267-283.

Manetti, G. (2011) 'The quality of stakeholder engagement in sustainability reporting: empirical evidence and critical points', Corporate Social Responsibility and Environmental Management, Vol. 18, No. 2, pp.110-122.

Marty, P.F. (2008) 'Museum websites and museum visitors: digital museum resources and their use', Museum Management and Curatorship, Vol. 23, No. 1, pp.81-99.

Nuccio, M. and Bertacchini, E. (2016) 'Big data analytics in the arts and cultural industrial implication for cultural economics, policy and management', Paper presented at the XXVIII Sinergie Annual Conference 'Management in a Digital World, Decisions, Productions, Communications', Udine, Italy. 
Owen, D.L., Swift, T. and Hunt, K. (2001) 'Questioning the role of stakeholder engagement in social and ethical accounting auditing and reporting', Accounting Forum, Vol. 25, No. 3, pp.264-282.

Paris, C.M., Lee, W. and Serry, P. (2010) 'The role of social media in promoting special events: acceptance of Facebook events', in Gretzel, U., Law, R. and Fuchs, M. (Eds.): Information and Communication Technologies in Tourism, pp.531-541, Springer, Vienna.

Park, H. and Reber, B.H. (2008) 'Relationship building and the use of web sites: how Fortune 500 corporations use their web site to build relationships', Public Relations Review, Vol. 34, No. 4, pp.409-411.

Parry, R. (2007) Recording the Museum: Digital Heritage and Technologies of Change, Routledge, London-New York.

Sibilio Parri, B. and Manetti, G. (2014) 'Il dialogo fra musei e stakeholders tramite internet: il caso delle Soprintendenze Speciali per il patrimonio storico, artistico ed etnoantropologico e per i Poli museali', Il Capitale Culturale, Vol. 9, pp.123-153.

Simon, N. (2007) 'Discourse in the Blogosphere: what museums can learn from Web 2.0', Museums \& Social Issues, Vol. 2, No. 2, pp.257-274.

Smørdal, O., Stuedahl, D. and Sem, I. (2014) 'Experimental zones: two cases of exploring frames of participation in a dialogic museum', Digital Creativity, Vol. 25, No. 3, pp.224-232.

Song, F.W. (2010) 'Theorizing Web 2.0', Information, Communication \& Society, Vol. 13, No. 2, pp.249-275.

Srinivasan, R., Boast, R., Furner, J. and Becvar, K. (2009) 'Perspective: digital museums and diverse cultural knowledge: moving past the traditional catalog', The Information Society, Vol. 25, No. 4, pp.265-278.

Statista (2018) Most used Social Media in Italy in 2018, By Type [online] https://www.statista.com (accessed 31 January 2019).

Su, N., Reynolds, D. and Sun, B. (2015) 'How to make your Facebook posts attractive - a case of a leading budget hotel brand fan page', International Journal of Contemporary Hospitality Management, Vol. 27, No. 8, pp.1772-1790.

Suzić, B., Karlíček, M. and Stříteský, V. (2016a) 'Social media engagement of Berlin and Prague museums', The Journal of Arts Management, Law, and Society, Vol. 46, No. 2, pp.73-87.

Suzić, B., Karlíček, M. and Stř́teský, V. (2016b) 'Adoption of social media for public relations by museums', Central European Business Review, Vol. 5, No. 2, pp.5-16.

Thomson, K., Purcell, K. and Rainie, L. (2013) Arts Organizations and Digital Technologies, Pew Research Center's Internet and American Life Project, Washington.

Toffler, A. (1980) The Third Wave, Bantam Books, New York.

Trottier, D. and Fuchs, C. (2015) Social Media, Politics and the State: Protest, Revolutions, Riots, Crime and Policing in the Age of Facebook, Twitter and YouTube, Routledge, New York.

Trusov, M., Bucklin, R.E. and Pauwels, K. (2009) 'Effects of word-of-mouth versus traditional marketing: findings from an internet social networking site', Journal of Marketing, Vol. 73, No. 5, pp.90-102.

Vassilakis, C., Antoniou, A., Lepouras, G., Poulopoulos, V., Wallace, M., Bampatzia, S. and Bourlakos, I. (2017) 'Stimulation of reflection and discussion in museum visits through the use of social media', Social Network Analysis and Mining, Vol. 7, p.40 [online] https://doi.org/10.1007/s13278-017-0460-3.

Verhoef, P.C. and Lemon, K.N. (2013) 'Successful customer value management: key lessons and emerging trends', European Management Journal, Vol. 31, No. 1, pp.1-15.

Waters, R.D., Burnette, E., Lamm, A. and Lucas, J. (2009) 'Engaging stakeholders through social networking: how nonprofit organizations are using Facebook', Public Relations Review, Vol. 35, No. 2, pp.102-106. 
Wright, K.D. and Hinson, M.D. (2008) 'How blogs and social media are changing public relations and the way it is practiced', Public Relations Journal, Vol. 2, No. 2, pp.1-21.

Zafiropoulos, K., Vrana, V. and Antoniadis, K. (2015) 'Use of twitter and Facebook by top European museums', Journal of Tourism, Heritage \& Services Marketing, Vol. 1, No. 1, pp.16-24.

Zarrella, D. (2010) The Social Media Marketing Book, O'Really Media, Sebastopol. 